IRYNA KURLAK

Wydział Nauk Pedagogicznych

Uniwersytet Kardynała Stefana Wyszyńskiego

Warszawa
Forum Pedagogiczne $2016 / 1$

Wpłynęło: 2.03.2016 Zatwierdzono do druku: 7.04.2016

\title{
WIĘZIENNA SŁUŻBA ZDROWIA W TROSCE O STAN OSÓB PRZEWLEKLE CHORYCH, ZABURZONYCH I NIEPEŁNOSPRAWNYCH
}

Streszczenie: $\mathrm{W}$ artykule są analizowane działania więziennej służby zdrowia wobec osadzonych z różnymi problemami zdrowotnymi. Omawia się sytuację kilku grup osób zakażonych HIV, chorych na gruźlicę, uzależnionych od alkoholu i narkotyków, niepełnosprawnych fizycznie i z zaburzeniami psychicznymi. Podkreśla się potrzebę zwiększenia finansowania więziennej służby zdrowia i liczby personelu medycznego, a także polepszenia warunków materialno-bytowych i sanitarnych w procesie profilaktyki zachowań suicydalnych oraz poprawienia stanu zdrowia osób tymczasowo aresztowanych i skazanych.

Słowa kluczowe: niepełnosprawni, zaburzeni, przewlekle chorzy, służba zdrowia, więzienie

\section{Wprowadzenie}

Wśród więźniów na szczególną uwagę personelu oraz badaczy tej problematyki zasługują osoby zaburzone psychicznie, przewlekle chore, niepełnosprawne, uzależnione od środków psychoaktywnych. Wynika to z tego, że osadzenie w zakładzie karnym jest sytuacją szczególnie trudną, kryzysową, nawet dla człowieka zdrowego, nie mówiąc już o osobach, których funkcjonowanie było utrudnione na wolności, a jeszcze bardziej skomplikowało się w sytuacji uwięzienia. Znaczącą rolę w procesie niesienia im pomocy odgrywa więzienna służba zdrowia.

\section{Ogólna charakterystyka więziennej służby zdrowia}

Więzienna służba zdrowia zapewnia opiekę zdrowotną osobom pozbawionym wolności i tymczasowo aresztowanym zgodnie z przepisami Kodeksu karnego wykonawczego i Rozporzadzeniem Ministra Sprawiedliwości z dnia 31 października 2003 roku w sprawie szczegółowych zasad, zakresu i trybu udzielania świadczeń zdrowotnych osobom pozbawionym wolności przez zakłady opieki zdrowotnej dla osób pozbawionych wolności (Rozporządzenie... 2004). 
„W art. 102 kkw zaznacza się, iż osoba pozbawiona wolności ma prawo w szczególności do: odpowiedniego - ze względu na zachowanie zdrowia - wyżywienia, odzieży, warunków bytowych, pomieszczeń oraz opieki lekarskiej i sanitarnej. Zapewnia się jej również bezpłatne świadczenia zdrowotne, leki i artykuły sanitarne, a w szczególnie uzasadnionych wypadkach niezbędne protezy. Przepis par. 2 art. 115 reguluje przypadki, kiedy skazanemu należy bezpłatnie dostarczyć protezy, przedmioty ortopedyczne i środki pomocnicze, a jest to w sytuacji, gdy brak tych przedmiotów lub środków mógłby pogorszyć jego stan zdrowia lub uniemożliwić odbywanie kary pozbawienia wolności" (Królikowska 2010, s. 218).

W związku z tym osoby skazane poddaje się wstępnym, okresowym i kontrolnym badaniom lekarskim. „Badania wstępne przechodzą osoby skierowane do jednostek penitencjarnych niezwłocznie po przyjęciu do zakładu karnego, nie później niż w terminie trzech dni roboczych od przyjęcia. Badaniom kontrolnym zaś poddaje się osoba pozbawiona wolności przed przetransportowaniem oraz zwolnieniem z zakładu karnego" (Ickiewicz-Sawicka 2005, s. 67).

Do zakresu działalności więziennej służby zdrowia należy w szczególności:

„1. zapewnienie osobom pozbawionym wolności świadczeń zdrowotnych, profilaktycznych, diagnostycznych, leczniczych i rehabilitacyjnych;

2. prowadzenie nadzoru nad warunkami zdrowotnymi, sanitarnymi oraz żywieniem w jednostkach penitencjarnych;

3. zaopatrzenie medyczne, zwłaszcza w leki, materiały medyczne, sprzęt i aparaturę medyczną" (Ickiewicz-Sawicka 2005, s. 67-68).

W uzasadnionych przypadkach, gdy świadczenia zdrowotne nie mogą być udzielane osobom pozbawionym wolności przez specjalnie wyznaczone do tego zakłady opieki zdrowotnej, w szczególności z powodu braku specjalistycznego sprzętu medycznego, mogą być one realizowane przez pozawięzienne publiczne zakłady opieki zdrowotnej (Ickiewicz-Sawicka 2005, s. 67-68).

Zgodnie z Narodowym Programem Zdrowia, Krajowym Programem Zapobiegania Zakażeniom HIV, Opieki nad Żyjącymi z HIV i Chorymi na AIDS oraz Narodowym Programem Zwalczania Gruźlicy i uwzględniając specyfikę placówek służby zdrowia Służby Więziennej, w ramach promocji zdrowia i oświaty zdrowotnej są prowadzone programy:

- zmniejszania rozpowszechnienia palenia tytoniu;

- zmniejszania szkód zdrowotnych spowodowanych spożywaniem alkoholu;

- zmniejszania szkód zdrowotnych spowodowanych używaniem środków psychoaktywnych;

- zwiększania skuteczności zapobiegania chorobom zakaźnym;

- tworzenia warunków aktywizujących osoby niepełnosprawne (Księga jubileuszowa... 2009, s. 146).

W strukturze każdej jednostki penitencjarnej w Polsce funkcjonuje zakład opieki zdrowotnej (zoz), świadczący usługi z zakresu podstawowej opieki zdrowotnej. Ogółem działa 155 ambulatoriów. Zadania podstawowej opieki zdrowotnej są 
realizowane przez 650 lekarzy, ponad 850 pielęgniarek i 240 osób innego personelu medycznego (Ksiega jubileuszowa... 2009, s. 145).

„Więzienna służba zdrowia dysponuje również 14 szpitalami z 41 oddziałami o różnym profilu, o łącznej liczbie 1287 łóżek. W szpitalach tych znajdują się następujące oddziały: chorób wewnętrznych (11 oddziałów na terenie całego kraju) - w jednym oddział wewnętrzny dla przewlekle chorych, chirurgiczne (7), psychiatryczne (6), przeciwgruźlicze (4), detoksykacyjne (2) oraz po jednym oddziale neurologicznym, intensywnej opieki medycznej, ortopedycznym, laryngologicznym, okulistycznym, urologicznym, zakaźnym (hepatologicznym), ginekologiczno-położniczym, rehabilitacyjnym i dermatologicznym" (Ickiewicz-Sawicka 2005, s. 68-69).

Przy wszystkich szpitalach więziennych działają komisje lekarskie. Ich zadaniem jest kolegialne (co najmniej 3-osobowe) orzekanie o stanie zdrowia i niezbędnych świadczeniach zdrowotnych dla osób osadzonych w aresztach śledczych i zakładach karnych. Orzeczenia tych komisji stanowią podstawę postanowień o uchyleniu tymczasowego aresztowania lub udzieleniu przerwy w odbywaniu kary w przypadkach, gdy więzienna służba zdrowia nie jest w stanie zapewnić niezbędnego leczenia badanym bądź też stwierdza się u nich ciężką chorobę uniemożliwiającą wykonywanie kary (Kolarczyk 1995a, s. 10).

W 2008 roku w więziennej służbie zdrowia pracowało 909 lekarzy zatrudnionych na 466,95 etatu i 909 pielęgniarek zatrudnionych na 947,8 etatu oraz było 417 etatów przeznaczonych dla innych pracowników więziennej służby zdrowia (Księga jubileuszowa... 2009, s. 148).

Od kilku lat więzienna służba zdrowia bierze udział w Programie WHO „Zdrowie w więzieniu”, czego wymiernym efektem jest wymiana doświadczeń oraz możliwość korzystania z gotowych rozwiązań, wypracowanych w innych systemach penitencjarnych. Polskie więziennictwo uczestniczy również w programie na rzecz osób uzależnionych w więzieniach europejskich (ENDIP), finansowanym przez Komisję Europejską (Księga jubileuszowa... 2009, s. 147).

\section{Pacjenci więziennej służby zdrowia}

Wśród pacjentów więziennej służby zdrowia można wyodrębnić kilka szczególnych grup ze względu na ich liczebność, znaczenie epidemiologiczne czy koszty leczenia. Pierwszą z nich stanowią pacjenci zakażeni HIV. Należy podkreślić duże zmiany, jakie nastąpiły w traktowaniu tej grupy więźniów od 1989 roku, kiedy wykonywano badania przesiewowe i izolowano nosicieli w trakcie odbywania kary. Obecnie badania w kierunku HIV proponowane są każdemu nowo przybyłemu oraz wykonywane tylko za zgodą osadzonego przy zachowaniu pełnej anonimowości i zasady tajemnicy lekarskiej (Księga jubileuszowa... 2009, s. 147). Biuro Służby Zdrowia i Biuro Penitencjarne Centralnego Zarządu Służby Więziennej opracowały harmonogram działań w ramach Krajowego Programu Zapobiegania Zakażeniom HIV, 
Opieki nad Żyjącymi z HIV i Chorymi na AIDS. Wyszczególniono następujące zadania:

„1. rutynowe proponowanie wykonywania badań w kierunku HIV osadzonym w zakładach penitencjarnych;

2. prowadzenie edukacji osadzonych ze szczególnym uwzględnieniem młodocianych;

3. zapewnienie osadzonym dostępu do materiałów edukacyjnych związanych z HIV/AIDS;

4. monitorowanie zjawisk związanych $\mathrm{z}$ HIV/AIDS w jednostkach penitencjarnych;

5. stałe uaktualnianie i wprowadzanie jednolitych standardów opieki nad osobami żyjącymi z HIV/AIDS w placówkach penitencjarnych;

6. zapewnienie funkcjonowania więziennej służby zdrowia w ogólnopolskim komputerowym systemie dystrybucji leków antyretrowirusowych oraz w bazie danych o osobach leczonych (średnio w programie uczestniczy ponad 100 osób osadzonych w jednostkach penitencjarnych);

7. nadzorowanie i egzekwowanie przestrzegania przez personel więziennej służby zdrowia procedur medycznych związanych z pracą z materiałem zakaźnym;

8. realizowanie programu redukcji szkód w odniesieniu do zakażeń HIV, HBs, HCV dla więziennej służby zdrowia;

9. współpracowanie z organizacjami rządowymi i pozarządowymi;

10. realizowanie poradnictwa medycznego przed i po wykonaniu testu w kierunku HIV/AIDS” (Ickiewicz-Sawicka 2005, s.69).

Żyjący z HIV wymagający hospitalizacji są kierowani do więziennych oddziałów szpitalnych przeznaczonych do leczenia tej grupy chorych. „W 2007 roku u osób pozbawionych wolności w polskich jednostkach penitencjarnych stwierdzono 1145 przypadków infekcji wirusem HIV, z czego 81 stanowiły przypadki nowo wykryte 378 osób zakażonych HIV przebywało w aresztach śledczych i w więzieniach" (Ickiewicz-Sawicka 2005, s. 69).

Następną grupę pacjentów stanowią osoby uzależnione od środków psychoaktywnych, przyjmujące narkotyki dożylnie i używające do tego celu wspólnych igieł i strzykawek, co jest najbardziej ryzykowne z punktu widzenia rozpowszechniania się HIV. Są to ludzie, którzy już wiele razy próbowali zerwać z nałogiem, ale zawsze kończyło się to porażką. To właśnie do takich pacjentów skierowane są programy substytucyjne. Programy substytucji metadonowej są niezbędnym uzupełnieniem oferty terapeutycznej (Księga jubileuszowa... 2009, s. 147).

W 2001 roku Instytut Psychiatrii i Neurologii realizował badania ankietowe na losowej, reprezentatywnej próbie 1186 mężczyzn osadzonych w zakładach karnych i aresztach śledczych położonych na terenie całego kraju. Uzyskane wyniki sprowadziły się do następujących wniosków:

"- wśród osadzonych w jednostkach penitencjarnych 19,5\% okazjonalnie zażywało narkotyki przed pozbawieniem wolności; 
- najpopularniejszym narkotykiem przed pozbawieniem wolności wśród osadzonych były marihuana i haszysz $(38,7 \%)$ oraz amfetamina $(36,0 \%)$, podobnie jak to ma miejsce wśród ogółu młodzieży;

- skala używania narkotyków w warunkach izolacji więziennej jest znaczna, $22 \%$ osadzonych ma za sobą takie doświadczenia. Wśród osadzonych w przedziale wiekowym 20-24 lata wskaźnik ten przekracza 33\%;

- wśród substancji najczęściej przyjmowanych przez osadzonych w zakładach karnych i aresztach śledczych dominują leki uspokajające i nasenne przyjmowane bez przepisu lekarza $(25,6 \%)$, marihuana i haszysz $(21,3 \%)$ oraz amfetamina (5,6\%). Następnie LSD i inne halucynogeny $(5,1 \%)$, kokaina $(5 \%)$, ecstasy $(4,7 \%)$;

- użytkowanie narkotyków w iniekcji potwierdziło 3,3\% osadzonych, w tym 1\% przyznało się do stosowania wspólnych igieł i strzykawek, co grozi poważnymi skutkami epidemiologicznymi;

- używanie narkotyków w zakładzie karnym wiąże się z młodym wiekiem, praktycznie nie dotyczy osadzonych po 40. roku życia, z wcześniejszą karalnością, mieszkaniem w mieście - szczególnie dużym, długim pobytem w jednostce penitencjarnej. Ponieważ większość osadzonych spełnia te kryteria (są młodzi - do 35. roku życia, pochodzą z miast i wchodzili już w konflikt z prawem), można stwierdzić, że potencjalnymi użytkownikami narkotyków jest większość osadzonych. Warunkiem koniecznym jest posiadanie środków na ich zakup;

- na podstawie swoich doświadczeń i oceny sytuacji w trakcie badania osadzeni uważają, że narkotyki są dostępne w zakładach karnych i to o wiele bardziej niż również zakazane napoje alkoholowe" (Dubiel, Majcherczyk 2006, s. 54-55).

„Osoby uzależnione, przewlekle chore i niepełnosprawne odbywają karę pozbawienia wolności w systemie terapeutycznym. Wykonywanie kary w tym systemie polega na realizacji indywidualnego programu terapeutycznego i odbywa się przede wszystkim na oddziale terapeutycznym o określonej specjalizacji, na którym pobyt nie musi być dobrowolny i ma charakter przejściowy. Indywidualny program terapeutyczny obejmuje zwłaszcza rodzaje i formy oddziaływań psychokorekcyjnych, lekarskich i rehabilitacyjnych, którym skazani zostają poddani. Oprócz tego program ten zawiera: rodzaje i formy oddziaływań wychowawczych, nauczania, zajęć kulturalno-oświatowych, sportowych i wychowania fizycznego, warunki zatrudnienia, zakres i sposób kontaktów z rodziną i innymi osobami bliskimi, zasady wywiązywania się z nałożonych obowiązków oraz korzystania z przysługujących uprawnień" (Pustkowiak 2005, s. 37).

Aktualnie baza terapeutyczna więziennictwa dla osób uzależnionych składa się z 33 oddziałów, w tym 20 oddziałów terapeutycznych dla skazanych uzależnionych od alkoholu dysponujących łącznie 649 miejscami oraz 13 oddziałów 
terapeutycznych dla skazanych uzależnionych od środków odurzających lub psychotropowych z 479 miejscami (Dubiel, Majcherczyk 2006, s. 54-55).

Programy psychoterapii uzależnień, realizowane we wszystkich oddziałach terapeutycznych dla uzależnionych, należą do kategorii poznawczo-behawioralnych. Jako takie powinny w maksymalnym stopniu uwzględniać wiedzę o tym, co decyduje o efektywności tego podejścia. „Skuteczne interwencje poznawczo-behawioralne mają charakter wielowymiarowy. Program ma charakter wielowymiarowy wówczas, jeżeli jego cele tworzą odpowiednio szerokie spektrum. We wszystkich programach terapeutycznych występują dwa główne cele terapii: abstynencja oraz zapobieganie powrotom do przestępstwa, a ponadto szereg celów szczegółowych. Drugi, równie ważny cel nie ma często adekwatnego rozwinięcia wśród celów szczegółowych ani w zawartości programu. Tylko w przypadku niektórych skazanych można liczyć na to, że sam fakt przejścia z sukcesem terapii uzależnienia przyczyni się do znaczącego zmniejszenia prawdopodobieństwa recydywy. W przypadku wielu innych skazanych potrzebne są ponadto inne oddziaływania, w szczególności zaś szerzej zakrojona restrukturyzacja sfery poznawczej, obejmująca prezentowane przez nich zniekształcenia poznawcze, postawy i wzorce zachowań, mające wpływ na popełnianie przestępstw" (Dubiel, Majcherczyk 2006, s. 67-68).

Efekty programów terapeutycznych po jakimś czasie zanikają, o ile nie wzmacnia się zmian w zachowaniu absolwentów i nie podtrzymuje motywacji do modyfikacji dotychczasowego stylu życia. Dlatego po programie terapeutycznym jego uczestnicy powinni mieć możliwość udziału w spotkaniach grup samopomocowych osób uzależnionych oraz innych formach opieki postterapeutycznej. „Skazani, którzy dokonali szczególnie spektakularnych przewartościowań, powinni być wykorzystywani w roli liderów rówieśniczych; można im powierzać pewne zadania do realizacji w ramach prowadzonego w jednostkach programu profilaktyki uzależnień. W warunkach relatywnie krótkich programów terapeutycznych rośnie znaczenie oddziaływań podejmowanych zarówno przed, jak i po terapii" (Dubiel, Majcherczyk 2006, s. 69-70).

Jest to szczególnie ważne $\mathrm{z}$ uwagi na to, że uzależnienie jest podstawowym czynnikiem etiologicznym przestępstw popełnianych przez osoby uzależnione od środków odurzających lub substancji psychotropowych (Kozioł 2011, s. 6).

Kolejną grupę osadzonych potrzebujących terapii stanowią osoby uzależnione od alkoholu. Należy szczególnie podkreślić w tym miejscu znaczenie terapeutycznego programu Atlantis, który został opracowany specjalnie dla więziennej populacji osób uzależnionych, co zwiększa jego efektywność.

„Poważny problem występuje w terapii osób z psychotycznymi zaburzeniami alkoholowymi, między innymi delirium tremens. Zwłaszcza początkowy okres uwięzienia staje się dla takich osób szczególnie trudnym przeżyciem, ponieważ izolacja penitencjarna stanowi czynnik usposabiający do wystąpienia zespołu abstynencyjnego i delirium. Łączy się to bowiem właśnie z nagłym odstawieniem alkoholu - nieraz po długich ciągach pijackich, przeżyciem wstrząsu psychicznego 
na skutek pozbawienia wolności, reakcją szoku na traumatyczne warunki wykonywania tymczasowego aresztowania" (Kolarczyk 1994, s. 39).

W praktyce penitencjarnej delirium tremens niewątpliwie stwarza przede wszystkim problemy medyczne, ale nie tylko. Poza opieką medyczną delirycy wymagają także odpowiedniego traktowania penitencjarnego. Powinno mieć ono co najmniej cztery cele, a mianowicie:

„- możliwie szybkie rozpoznawanie osadzonych, a ściśle biorąc, ich zachowań, wskazujących na wysokie ryzyko wystąpienia delirium i związanych z nim zaburzeń postępowania;

- zapewnienie delirykom tzw. pomocy przedlekarskiej i właściwego nadzoru w okresie zwiastunowym zaburzeń, tj. poprzedzającym wystąpienie objawów klinicznych choroby;

- zapobieganie za pomocą stosownych oddziaływań penitencjarnych ewentualnym nawrotom delirium po zakończeniu postępowania farmakoterapeutycznego;

- ustanowienie szczególnych warunków odpowiedzialności dyscyplinarnej i materialnej osadzonych, którzy w stanie majaczenia drżennego dopuścili się naruszenia obowiązujących ich przepisów - dokonali samouszkodzeń i napaści na inne osoby, wyrządzili szkody materialne w majątku zakładu penitencjarnego, spowodowali zagrożenia porządku i bezpieczeństwa itp." (Kolarczyk 1994, s. 42).

Prawdopodobieństwo wystąpienia nawrotów delirium po ponownym spożyciu alkoholu wydaje się większe w zakładach penitencjarnych niż w warunkach wolnościowych. Decyduje o tym szczególna podatność psychotyczna osadzonych przebyte przez nich choroby, objawy niepełnosprawności, wyniszczenie organizmu, narażenie na różnego rodzaju silne lub długotrwałe stresy. „Może to również wiązać się z nieodosobnionymi przypadkami spożywania przez osadzonych alkoholu niekonsumpcyjnego, np. samogonu, alkoholi technicznych i skażonych, różnego rodzaju środków zastępczych. Tym bardziej więc niezbędne jest pouczanie osadzonych deliryków po zakończeniu ich leczenia o niebezpieczeństwie nawrotu psychozy i możliwościach zminimalizowania tego zagrożenia. Nie można jednak na tym kończyć. Osadzonego należy ponadto skłaniać do poddania się alkoholowej terapii odwykowej - jeśli jest on chorobowo uzależniony, a przynajmniej do szukania pomocy lekarskiej w detoksykacji i leczeniu zespołu abstynencyjnego w razie ewentualnego powtórzenia się ekscesów pijackich. Powinno się oferować specjalistyczną pomoc - medyczną, psychologiczną, wychowawczą, prawną, w usprawnianiu niewydolności somatycznej i psychicznej" (Kolarczyk 1994, s. 42).

Kolejną grupę osób osadzonych stanowią chorzy na gruźlicę. Zwalczanie tej choroby wśród więźniów jest integralną częścią Narodowego Programu Zwalczania Gruźlicy i odbywa się przy współpracy i pod kontrolą Instytutu Gruźlicy i Chorób Płuc. Celem jest wykrycie zachorowań w jak najwcześniejszym okresie choroby, aby szybko wdrożyć właściwe leczenie i wyeliminować źródło zakażenia. Służą temu badania osadzonych przy przyjęciu do jednostki penitencjarnej oraz profilaktyka 
prowadzona corocznie wśród osób odbywających karę pozbawienia wolności (Księga jubileuszowa... 2009, s. 148).

Osadzeni ze stwierdzonymi zmianami w płucach są kierowani na diagnostykę w oddziałach chorób płuc. Potwierdzenie gruźlicy skutkuje wdrożeniem nadzorowanego leczenia przeciwprątkowego, zgodnie ze strategią WHO. Leczenie jest przeprowadzane $\mathrm{w}$ warunkach szpitalnych $\mathrm{z}$ wyjątkiem osób, u których termin zakończenia wyroku jest krótszy od czasu przewidywanego leczenia. O fakcie wykrycia, leczenia czy też wypisania pacjenta z czynną gruźlicą informowana jest właściwa ze względu na miejsce jego stałego pobytu terenowa poradnia gruźlicy i chorób płuc (Księga jubileuszowa... 2009, s. 148).

W 2007 roku u osób pozbawionych wolności w polskich jednostkach penitencjarnych stwierdzono 275 przypadków czynnej zakaźnej gruźlicy płuc, z czego 186 stanowiły przypadki nowo wykryte (Księga jubileuszowa... 2009, s. 148).

Szczególną grupę osadzonych stanowią osoby niepełnosprawne fizycznie. W 2006 roku w jednostkach penitencjarnych przebywało 1066 niepełnosprawnych, z czego zdecydowaną większość stanowili osadzeni z upośledzeniem narządu ruchu $(79,7 \%)$. Pozostali to niepełnosprawni w zakresie zaburzeń głosu, mowy, z chorobami słuchu, narządu wzroku, układu oddechowego, krążenia, pokarmowego, układu moczowo-płciowego i chorobami neurologicznymi. $Z$ tej grupy niepełnosprawność z powodu chorób neurologicznych (niedowłady kończyn górnych i dolnych) dotyczyła największego odsetka więźniów - 13,3\% (Księga jubileuszowa... 2009, s. 148).

Znaczna część $(29,4 \%)$ osadzonych niepełnosprawnych w zakresie upośledzenia narządu ruchu wymaga przyznania kul ortopedycznych, a 4\% porusza się na wózku inwalidzkim. W czasie wykonywania kary pozbawienia wolności osadzeni niepełnosprawni fizycznie zostają objęci specjalistyczną opieką lekarską, psychologiczną oraz rehabilitacyjną (Księga jubileuszowa... 2009, s. 148).

W 2007 roku w jednostkach penitencjarnych przebywało 516 osadzonych niepełnosprawnych fizycznie. Z tej grupy $27 \%$ wymagało opieki rehabilitacyjnej, $22 \%$ - opieki lekarskiej, natomiast $8 \%$ - opieki psychologa.

Wykonywanie kary wobec tej kategorii skazanych uwzględnia w szczególności potrzebę zapobiegania pogłębieniu się stopnia niepełnosprawności oraz przystosowania do samodzielnego życia. Dla skazanych niewidomych zorganizowano w Zakładzie Karnym w Bydgoszczy-Fordonie program rehabilitacyjny, obejmujący między innymi ukończenie kursu orientacji przestrzennej i naukę pisma Braille’a. Ponadto prowadzi się prace modernizacyjne, przystosowujące jednostki penitencjarne dla niepełnosprawnych z dysfunkcją narządu ruchu (Księga jubileuszowa... 2009, s. 148).

Osadzonym z zaburzeniami psychicznymi, którzy wymagają hospitalizacji i związanej z nią farmakoterapii, zapewnia się opiekę w oddziałach psychiatrycznych, gdzie przede wszystkim przeprowadza się obserwacje na polecenie sądu oraz leczy pacjentów, u których wystąpiły objawy choroby psychicznej w trakcie 
pobytu w izolacji więziennej. Jeżeli choroba nie ulega remisji, lekarze wnioskują o udzielenie przerwy w wykonywaniu kary i skierowanie do pozawięziennego szpitala psychiatrycznego.

„Znaczący wpływ diagnozy zdrowia psychicznego skazanego na rozstrzygnięcia zapadające w postępowaniu wykonawczym jest zauważalny już od momentu jego wszczęcia. Skazanego poddaje się badaniom psychologicznym, a także psychiatrycznym. W razie ustalonej potrzeby skazanego kieruje się do systemu terapeutycznego, który ma na celu zapobieganie pogłębieniu się patologicznych cech osobowości, przywrócenie równowagi psychicznej oraz kształtowanie zdolności współżycia społecznego i przygotowania do samodzielnego życia" (Kolarczyk 1995b, s. 57). Proces wykonywania kary wobec skazanych przebywających w tym systemie ma być dostosowany do potrzeb wynikających m.in. z leczenia (Kwieciński 2013, s. 38).

Nie jest to jedyne następstwo, jakie w obrębie procesu klasyfikacyjnego związane jest $\mathrm{z}$ badaniem psychologiczno-psychiatrycznym. Nie można zapominać o wprowadzonym w 2011 roku art. 88 par. 5b kkw, który przewiduje skierowanie z mocy prawa do zakładu karnego typu zamkniętego wszystkich skazanych, u których zdiagnozowano niepsychotyczne zaburzenia psychiczne (w tym zaburzenie preferencji seksualnych) bądź upośledzenie umysłowe.

Populacja więźniów odbywających karę pozbawienia wolności w oddziałach terapeutycznych jest znacznie zróżnicowana pod względem nozologicznym. Najliczniejszą grupę stanowią osoby z rozpoznaniem zaburzenia osobowości, przede wszystkim z osobowością dyssocjalną, ale także zaburzeniami osobowości uwarunkowanymi czynnikami organicznymi. Poza tym na oddziałach terapeutycznych znajdują się pacjenci z rozpoznaniem upośledzenia umysłowego lekkiego stopnia, zespołu psychoorganicznego, padaczki, a ponadto, choć w niewielkiej liczbie, neurotycy. Niejednokrotnie są to osoby z tzw. podwójną diagnozą, np. z rozpoznaniem osobowości dyssocjalnej i uzależnienia od substancji psychoaktywnych czy zespołu psychoorganicznego i uzależnienia od alkoholu (Gordon 2011, s. 251).

W terapii osób upośledzonych umysłowo stosowane są różne metody, w tym arteterapia. W procesie tym należy jednak uwzględniać ograniczenia w zakresie usprawnienia ogólnego poziomu inteligencji, który charakteryzuje tendencja do stałości. „Niemniej jednak - jak pisze Janina Florczykiewicz - biorąc pod uwagę fakt, że wyznacznikiem rozwoju, oprócz poziomu kompetencji umysłowych, jest całościowa struktura osobowości, wydaje się, że nie traci na aktualności obecny we współczesnej myśli resocjalizacyjnej postulat powiązania rozwoju predyspozycji twórczych z możliwością korektury psychologicznej - w kierunku modyfikacji wadliwego systemu normatywnego jednostki, podniesienia samooceny i poczucia własnej wartości. W perspektywie działań «naprawczych» diagnoza jednostek nieprzystosowanych społecznie o obniżonej sprawności intelektualnej dostarcza cennych wskazówek dla projektowanych programów korekcyjno-resocjalizacyjnych" (Florczykiewicz 2008, s. 61). 
Ważne miejsce w procesie terapii skazanych odgrywają warsztaty twórcze. „Pomysł na realizację warsztatów twórczych w oddziale terapeutycznym zakładu karnego jest wynikiem refleksji nad rolą kreatywności i rozwijających ją działań nie tylko w rozwoju czy terapii pacjentów oddziałów psychiatrycznych, lecz także w społecznej adaptacji jednostki. Kreatywność, jako kompetencja osobowa oparta na wykorzystaniu heurystyk, wspomaga proces rozwiązywania problemów, rozwija niestereotypowe myślenie, przyczyniając się do lepszego rozumienia siebie, świata, relacji interpersonalnych, co wpisane jest w postulat twórczej resocjalizacji” (Florczykiewicz 2012, s. 122).

Jak już wspomniano wcześniej, nie wszystkie zaburzone osoby podlegają procesowi terapii w zamkniętych warunkach zakładów karnych. „Z treści artykułu 31 par. 1 Kodeksu karnego wynika, że nie popełnia przestępstwa ten, kto z powodu choroby psychicznej, upośledzenia umysłowego lub innego zakłócenia czynności psychicznej nie mógł w czasie czynu rozpoznać jego znaczenia lub pokierować swoim postępowaniem. Oprócz choroby psychicznej powodem zniesienia poczytalności może być zarówno upośledzenie umysłowe w stopniu głębszym, jak i lekki zespół otępienny, tzn. wtórne znaczne obniżenie sprawności intelektualnej. Wymagają oni leczenia psychiatrycznego szpitalnego lub ambulatoryjnego, i po umorzeniu przez sąd postępowania karnego są kierowani pod opiekę odpowiednich placówek psychiatrycznych społecznej służby zdrowia. Ta grupa sprawców czynów zabronionych nie ponosi odpowiedzialności karnej, nie odbywa kary pozbawienia wolności i tym samym nie jest podmiotem zainteresowania personelu więziennego" (Gordon 2013, s. 49-50). Problem jednak często tkwi w tym, że na decyzję sądu o umorzeniu postępowania ta kategoria osób czeka dość długo w trudnych warunkach izolacji, co nasila objawy choroby.

Część osób z zaburzeniami psychicznymi trafia na oddziały psychiatrii sądowej. „Leczeniem psychiatrycznym w oddziałach psychiatrii sądowej obejmuje się przede wszystkim zdradzających objawy chorobowe obserwantów skierowanych na badania, ale nie tylko ich. Leczy się również pacjentów kierowanych z pozostałych oddziałów szpitali oraz przez miejscowe ambulatoria. Z reguły dotyczy to tzw. przypadków nagłych, niecierpiących zwłoki - chorych z ostrymi zaburzeniami psychotycznymi po zatruciu alkoholem, środkami odurzającymi lub psychotropowymi, chorych z zaostrzeniami zaburzeń zachowania przy nieprawidłowej osobowości, chorych z powikłaniami psychotycznymi w przebiegu różnego rodzaju reakcji sytuacyjnych, np. pooperacyjnych, pourazowych itd.” (Kolarczyk 1995a, s. 21).

Zastosowanie internacji psychiatrycznej z art. 94 par. 1 kk w związku z art. 93 kk ma miejsce, gdy zostaną spełnione następujące warunki:

„a) sprawca był niepoczytalny w czasie czynu zabronionego (art. 31 par. 1 kk);

b) popełnił czyn zabroniony o znacznym stopniu społecznej szkodliwości;

c) zachodzi wysokie prawdopodobieństwo, iż dopuści się tego czynu ponownie;

d) nie można w inny sposób osiągnąć wobec sprawcy celu leczniczo-terapeutycznego i rehabilitacyjnego" (Szwiejkowska 2013, s.10). 
U osadzonych, którzy nie są zdolni do zaadaptowania się w warunkach izolacji, w efekcie braku przystosowania i nasilenia negatywnych emocji często dochodzi do wystąpienia depresji. Najważniejszymi jej objawami są: zmiana nastroju, pojawienie się myśli o śmierci, poczucie braku własnej wartości, niska samoocena i poczucie winy, upośledzona zdolność koncentracji, drażliwość, zakłócenie snu i rytmu okołodobowego, charakteryzujące się np. wczesnym wybudzaniem, problemami z zasypianiem lub snem, oraz dzienne wahania nastroju, zmiana wagi i apetytu, obniżone libido, ogólny zanik zainteresowań i zredukowana aktywność społeczna. Depresja jest obciążeniem dla jednostki, znacznie ogranicza bowiem jej zdolność do podejmowania działań, a także wiąże się z wysokim ryzykiem popełnienia samobójstwa. Rozpoznawanie depresji jest trudne zwłaszcza w warunkach izolacji więziennej, gdzie często przebywają osoby, które mogą symulować pewne dolegliwości, toteż kluczowe staje się stosowanie rzetelnych narzędzi jej pomiaru (Chmielewska-Hampel, Wawrzyniak 2010, s. 78).

Najbardziej drastycznym przejawem nieprzystosowania osób skazanych z zaburzeniami w zachowaniu są próby samobójcze oraz dokonane suicydy. „Każde samobójstwo jako wypadek nadzwyczajny jest przedmiotem wewnętrznego postępowania wyjaśniającego, jak i dochodzenia prokuratorskiego, w wyniku których osoby pracujące w bezpośrednim kontakcie ze skazanym muszą odpowiedzieć na pytania, czy dopełniły wszelkich formalności mających na celu zapewnienie bezpieczeństwa osadzonemu. Wszelkie zaniedbania w tym względzie grożą zarówno konsekwencjami służbowymi, jak i karnymi” (Głowik, Matyba 2010, s. 5).

W ostatnim dziesięcioleciu liczba samobójstw kształtowała się w bardzo zróżnicowany sposób, przy czym zauważalna jest wyraźna tendencja spadkowa od 2000 do 2004 roku (z 49 do 30 dokonanych samobójstw). W 2005 roku nastąpił ich nieznaczny (32), a w 2006 roku wyraźny wzrost (42). Wzrost samobójstw w roku 2006 mógł mieć związek z jednoczesnym wzrostem populacji więziennej, a tym samym z przeludnieniem jednostek penitencjarnych, przy czym współczynnik samobójstw $(4,7)$ nie zmniejszył się w latach 2008 i 2009, kiedy to zmniejszyła się liczba osadzonych w izolacji więziennej (z $88646 \mathrm{w}$ roku 2006 do $83152 \mathrm{w}$ roku 2008). Jedną z przyczyn takiego stanu rzeczy może być bardzo wyraźne ograniczenie bazy lokalowej do prowadzenia różnego rodzaju oddziaływań resocjalizacyjnych w jednostkach penitencjarnych. Aby sprostać wymogom orzeczenia Trybunału Konstytucyjnego, zamieniono na cele mieszkalne dziesiątki pomieszczeń, w których realizowano wcześniej programy resocjalizacyjne bądź też zwykłe zajęcia kulturalno-oświatowe dla skazanych (222 świetlice oraz 287 innych pomieszczeń, w których prowadzono zajęcia terapeutyczne, odbywały się spotkania Anonimowych Alkoholików, mieściły się sale telewizyjne itp.). Były to niejednokrotnie jedyne miejsca, szczególnie w zakładach karnych typu zamkniętego, które pozwalały na przebywanie przez określony czas w ciągu dnia poza celą mieszkalną i stwarzały możliwość rozładowania w kontrolowanej i aprobowanej formie napięć emocjonalnych (Głowik, Matyba 2010, s. 10). 
Aby w sposób rzetelny móc ocenić skalę zjawiska, warto odnieść się także do statystyk innych krajów europejskich i zestawić ze sobą zarówno liczbę przebywających tam skazanych, jak i współczynnik samobójstw. Dla porównania można zaznaczyć, że w Niemczech, gdzie przebywa podobna do naszego kraju liczba skazanych, w omawianym okresie było trzykrotnie więcej skutecznych zamachów samobójczych niż w Polsce. „Współczynnik samobójstw w izolacji więziennej, to znaczy ich liczba na 10 tys. skazanych, jest w Polsce stosunkowo niski $(4,7)$, podczas gdy w krajach o najbardziej zbliżonej do Polski liczbie osadzonych wynosi on 16,1 (Francja), 11,4 (Anglia i Walia) i 8,5 (Włochy). Jedynie w Hiszpanii jest on niższy i wynosi 3,o" (Głowik, Matyba 2010, s. 10).

Wyniki badań Mariana Kopciucha wskazują, że „wśród osób pozbawionych wolności, które dokonały skutecznego zamachu samobójczego, stwierdza się bardzo wysoki odsetek (96\%) zaburzeń osobowości i zachowania o zróżnicowanej etiopatogenezie. Większość z nich jeszcze przed osadzeniem w zakładzie penitencjarnym wykazywała liczne objawy nieprzystosowania społecznego. Znacznie częściej dokonywały skutecznego zamachu samobójczego osoby tymczasowo aresztowane w początkowym etapie pobytu w izolacji więziennej niż osoby skazane wyrokiem sądowym" (Kopciuch 2001, s. 55).

Reasumując, w systemie penitencjarnym przebywa znaczna liczba osób chorych, zaburzonych oraz niepełnosprawnych fizycznie i psychicznie z różnymi nozologiami. Więzienna służba zdrowia dokłada znacznych wysiłków, by nieść różnoraką pomoc w przystosowaniu skazanych do traumatycznych warunków izolacji więziennej, stosownym leczeniu chorób i terapii zaburzeń, a także aktywizacji osób niepełnosprawnych. W tym procesie znaczącą rolę odgrywają różne narodowe i europejskie programy profilaktyki i zwalczania chorób. Niemniej jednak są też negatywne elementy, takie jak: niewystarczająca liczba personelu zatrudnionego w pełnym wymiarze czasu w zakładach karnych i aresztach śledczych, przeludnienie więzień, powodujące ciasnotę w celach mieszkalnych, oraz niedobór pomieszczeń do realizacji zadań terapeutyczno-resocjalizacyjnych, niewystarczający poziom finansowania działań polegających na niesieniu adekwatnej pomocy profilaktycznej, diagnostycznej i leczniczo-rehabilitacyjnej osadzonym z problemami zdrowotnymi.

\section{Bibliografia}

Chmielewska-Hampel A., Wawrzyniak M. (2010). Depresja i psychotyzm u więźniów. „Przegląd Więziennictwa Polskiego”, nr 66, s. 77-85.

Dubiel K., Majcherczyk A. (2006). Polski system terapii skazanych uzależnionych od narkotyków. „Przegląd Więziennictwa Polskiego”, nr 52-53, s. 53-70.

Florczykiewicz J. (2008). Kompetencje twórcze wychowanków zakładów poprawczych o obniżonej sprawności intelektualnej. „Szkoła Specjalna”, nr 5, s. 61-69. 
Florczykiewicz J. (2012). Warsztaty twórcze w resocjalizacji skazanych z niepsychotycznymi zaburzeniami osobowości. „Szkoła Specjalna”, nr 3, s. 121-132.

Głowik T., Matyba A. (2010). Samobójstwa osadzonych w latach 2006-2009. „Przegląd Więziennictwa Polskiego", nr 66, s. 5-18.

Gordon M. (2013). Obraz kliniczny i postępowanie z osobami skazanymi z zastosowaniem art. 31 par. 2 Kodeksu karnego. „Przegląd Więziennictwa Polskiego”, nr 81, s. 59-6o.

Gordon M. (2011). Rekomendacja 1235 (1944) Zgromadzenia Parlamentarnego Rady Europy o psychiatrii i prawach człowieka. Komentarz. „Przegląd Więziennictwa Polskiego", nr 72-73, s. 251-26o.

Ickiewicz-Sawicka M. (2005). Opieka medyczna nad więźniami żyjącymi z HIV i chorymi na AIDS w świetle opinii osób pozbawionych wolności oraz personelu penitencjarnego. „Przegląd Więziennictwa Polskiego”, nr 47-48, s. 65-76.

Kolarczyk T. (1995a). Oddziały psychiatrii sadowej w zakładach penitencjarnych (powstanie, rozwój, perspektywy). „Przegląd Więziennictwa Polskiego”, nr 11, s. 9-21.

Kolarczyk T. (1995b). Terapeutyczny system wykonywania kary pozbawienia wolności. „Przegląd Więziennictwa Polskiego”, nr 10, s. 57-69.

Kolarczyk T. (1994). Traktowanie osadzonych z psychotycznymi zaburzeniami alkoholowymi. „Przegląd Więziennictwa Polskiego”, nr 6-7, s. 38-54.

Kopciuch M. (2001). Analiza przyczyn i uwarunkowań samobójstw dokonanych przez osoby pozbawione wolności w zakładach penitencjarnych w Polsce w latach 1995-1997. „Przegląd Więziennictwa Polskiego”, nr 30, s. 55-63.

Kozioł T. (2011). Wybrane zagadnienia warunkowego umorzenia postępowania karnego wobec sprawcy uzależnionego lub używającego substancje psychoaktywne. „Probacja”, nr 2, s. 5-14.

Królikowska A. (2010). Regulacje prawne dotyczace opieki zdrowotnej osób pozbawionych wolności. „Przegląd Więziennictwa Polskiego”, nr 67-68, s. 210-221.

Kwieciński A. (2013). Rola diagnozy stanu zdrowia psychicznego skazanego w postępowaniu karnym wykonawczym. „Przegląd Więziennictwa Polskiego”, nr 8, s. 37-49.

Pustkowiak L. (2005). Przestępczość osób upośledzonych umysłowo w stopniu lekkim oraz ich terapia w zakładzie karnym. „Szkoła Specjalna”, nr 1, s. 36-44.

Rozporządzenie Ministra Sprawiedliwości z dnia 31 października 2003 roku w sprawie szczegółowych zasad, zakresu i trybu udzielania świadczeń zdrowotnych osobom pozbawionym wolności przez zakłady opieki zdrowotnej dla osób pozbawionych wolności. (2004). Dz.U. nr 204, poz. 1985.

Szwejkowska M. (2013). Stosowanie i wykonywanie leczniczych środków zabezpieczajacych $z$ art. 94 kk i art. 95a kk. „Przegląd Więziennictwa Polskiego”, nr 79, s. 5-29.

Szymanowski T. (red.) (2009). Księga jubileuszowa więziennictwa polskiego 19892009. Warszawa: Centralny Zarząd Służby Więziennej. 


\title{
THE ACTIVITY OF THE PRISON HEALTH SERVICE REGARDING CHRONICALLY ILL, DISABLED AND MENTALLY IMPAIRED PERSONS
}

\begin{abstract}
The article analyzes the activity of the prison health service regarding persons with different health problems. In this context the author considers several groups of people, namely HIV positive persons, consumptives, alcohol and drug addicts, physically disabled and mentally impaired persons. The article stresses the importance of increasing funding for the prison health service, the number of medical staff and improving health and living conditions in order to prevent suicidal behavior and to strengthen the health of temporarily arrested and convicted persons.
\end{abstract}

Key words: disabled, chronic invalid, mentally ill persons, health service, prison

Iryna Kurlak - profesor doktor habilitowana. Zainteresowania naukowe: patologie społeczne, pedagogika resocjalizacyjna, wiktymologia, konfliktologia. Współredaktorka publikacji: Suicydologiczne aspekty patologii społecznej (2014), Wybrane zagadnienia problematyki pomocy $i$ wsparcia $w$ rozwiązywaniu problemów ludzi $w$ różnym wieku (2012), Człowiek w obliczu trudnej sytuacji życiowej (2011), Wokót problematyki pomocy dziecku i rodzinie w sytuacji kryzysowej. Podejście interdyscyplinarne (2011), Współczesne zagrożenia psychospołecznego funkcjonowania człowieka (2010), Uwarunkowania, profilaktyka i resocjalizacja aspołecznych zachowań dzieci i młodzieży (2010), Pomoc dziecku i rodzinie w sytuacji kryzysowej: teoria, historia, praktyka (2008). Adres do korespondencji: ul. Jana III Sobieskiego 8/3, 35-002 Rzeszów. Adres e-mail: kie3691@gmail.com. 